\title{
Monitoring \& Evaluation Model Framework for IT Project Management at PT. XYZ
}

\author{
Fattah Hadi Saputro ${ }^{1}$, Mohammad Amin Soetomo ${ }^{1 *}$ and Nuki Agya Utama ${ }^{1}$ \\ 1 Department of Information Technology, Swiss German University, Tangerang \\ 15143, Indonesia \\ * Corresponding author, email: mohammad.soetomo@gmail.com
}

\begin{abstract}
There are projects implementation that have not been run accordance with the objective of desired project. Evaluation Model Framework in project management is very important to get the desire goals such as quality, cost and delivery. The main requirement to start the project implementation is a business case study where investment must be validated with related objectives of the project carried out. Investment in a company is not easy to implement, especially in the planning phase of project management. Nowadays technology is growing rapidly, investment in a company continues growing every year along with the company's business needs to be competitive with appropriate investment. This study aims to propose a new design IT framework on project management, starting alignment business strategy, IT goals, business requirements and business case by validating functional specification based on criteria and the project that have passed business cases meet the expectations of stakeholder needs.
\end{abstract}

\section{Introduction}

PT. XYZ has an IT issues in business side that need to be addressed. In previous planning, business users submitted initiatives to the IT Division and directly carried out the execution of the submission for those needs, it causes uncontrolled demand from each business unit and also one of the weaknesses in planning phase before implementing an IT project. For the next 5 years, there are approximately 50 IT Projects/Initiative, with annual budget 2MUSD of investment. For solving the problem, this research will focus to make sure planning phase before IT Project implementation that explain business issues and needs. Annual Activity Planning includes activities and steps of work starting from the preparation business case, allocation annual IT budgets, preparation IT portfolio program. If there is an ad hoc initiative, it will continue to ad hoc activities preparation of annual IT activities.

Every project has a defined scope (performance), schedule (time), and budget (cost). These three project parameters are referred to as the triple constraints of the project. These triple constraints are often illustrated by an equilateral triangle (also known as the Iron Triangle), as shown in Figure 1. The key characteristics of this triangle is that a change in one of the three constraints will affect at least one other constraint. A project manager must balance these constraints as well as the project quality for the success of the project. This balancing act often involves negotiations between the project manager and the project sponsor or owner customer (project owner) (Singh, 2016). Costs might include the costs to design and develop and/or maintain the project or project management improvement initiative, cost of resources, cost of travel and expenses, cost to train, overhead costs, etc (PMI, 2010).

Scope defines the work that must be done to complete the project. Schedule represents the duration of the project. Budget represents the estimated cost of completing the project. Quality stands for how well a product or service meets the pre-defined specifications or requirements and how satisfied the customer is. 


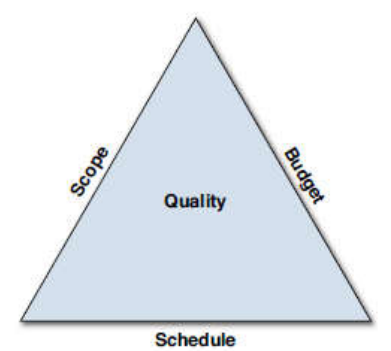

Figure 1. Triple Constraints of a project (Singh, 2016)

\section{Materials and Methods}

David Norton and Robert S Kaplan using the Balanced Scorecard as a strategic management system, how the company link measures from the four perspective (Kaplan \& David, 2007), Balance Scorecard is a strategy performance management tool - a semi-standard structured report, that can be used by managers to keep track of the execution of activities by the staff within their control and to monitor the consequences arising from these actions Aligning Vision, Mission, Destination \& Strategy Top to Bottom Approach. Combination of IT strategic alignment with IT governance could be an effective strategic innovation allowing organizations make efficient use of IT (Hosseinbeig, Moghadam, Vahdat, \& Moghadam, 2011).

COBIT is a framework that has been developed by IT Governance Institution that part of the Information System Audit and Control Association (Copy \& Indrajit, n.d.) Organization are expected to meet quality, compliance and security requirements for their governing and managing enterprise information technology. The major drivers for the development of COBIT include the need to provide more stakeholders a say in determining what they expect from information and related technology (what benefits at what acceptable level of risk and at what costs) and what their priorities are in ensuring that expected value is actually being delivered. Combination of IT strategic alignment with IT governance could be an effective strategic innovation allowing organizations make efficient use of IT (Hosseinbeig, Moghadam, Vahdat, \& Moghadam, 2011).

In the previous study, we used some literature from various sources to do alignment within business strategy and IT strategy to get the relationship until the program or initiative used as a project. The success of the project can include additional criteria related to organizational strategy and business delivery. How to align project management practices with the leading IT governance framework, it will be impossible to map directly to the 42 project management processes, 47 program management process, and 14 portfolio management processes into the 37 COBIT processes on the reference model (Rincon, I. (2012)). The right alignment between project management and IT governance provides a strong foundation to support strategic IT initiatives and provide measurable references to enable the business area to make the right decisions. Program and project processes are brought into COBIT via the BAI01 (Manage Programs and Projects) process. Evaluation of IT Project management governance using COBIT 5 framework (Rooswati, 2018). From the mapping done, it produces several processes COBIT 5 is suitable for problems in the company. we use several COBIT processes to analyze the processes related to project management as follows by considering, time, cost and quality.

The approach in this research is based on several process constraints as well as several processes carried out based on the COBIT domain, including BAI01, BAI02, BAI03, APO11 and MEA01 according to the detailed explanation attached. We divide several processes according to needs or project management constraints as described in Table 1, Table 2, and Table 3. 
Table 1. Process Alignment IT \& Business Strategy

\begin{tabular}{llll}
\hline Criteria & & COBIT Processes & Remark \\
\hline Alignment of IT Project and Business & BAI01 & Manage Programmes and Projects \\
$\begin{array}{l}\text { Strategy } \\
\text { Alignment of IT Project and IT }\end{array}$ & BAI01 & Manage Programmes and Projects \\
Programmes & & & \\
\hline
\end{tabular}

Table 2. Process Alignment IT Plan

\begin{tabular}{lll}
\hline Criteria & COBIT Processes & Remark \\
\hline $\begin{array}{l}\text { Nature and scope of the project are } \\
\text { confirmed and developed }\end{array}$ & BAI01, BAI03 & Project Scope \& Project Definition \\
$\begin{array}{l}\text { The scope of projects is clearly defined } \\
\text { and tied to building or enhancing }\end{array}$ & BAI01, BAI02, & $\begin{array}{l}\text { Project Plan (time frame, budget, } \\
\text { scope), Feasible Study, Project } \\
\text { business capability. }\end{array}$ \\
$\begin{array}{l}\text { Project time, cost, scope is defined } \\
\text { Prepare and execute a quality }\end{array}$ & BPO11 & $\begin{array}{l}\text { Project Plan (time frame, budget, } \\
\text { scope) } \\
\text { Quality management plan, Customer } \\
\text { requirements for quality management }\end{array}$ \\
\hline
\end{tabular}

Table 3. Process Alignment QCD Criteria \& Project Management

\begin{tabular}{lll}
\hline Criteria & COBIT Processes & Remark \\
\hline Time & BAI01 & $\begin{array}{l}\text { Project duration are met with time } \\
\text { frame }\end{array}$ \\
Cost & BAI01 & $\begin{array}{l}\text { Project Cost are met with project } \\
\text { budget allocation }\end{array}$ \\
Quality & APO11 & $\begin{array}{l}\text { Project scope are met with initial } \\
\text { Project Plan } \\
\end{array}$ \\
& $\begin{array}{l}\text { Project quality are met with user } \\
\text { requirement alongside UAT } \\
\text { Document as evidence } \\
\text { Each project is monitored, or baby } \\
\text { sited after implemented to ensure } \\
\text { quality }\end{array}$ \\
&
\end{tabular}

The last process is to make sure project are maintained and monitored that supported by project progress report as evidence we use MEA01 for controlling the Project Progress Report. the project management metrics of time, cost, scope, and quality have been the most important factors in defining the success of a project. More recently, practitioners and scholars have determined that project success should also be measured with consideration toward achievement of the project objectives.

The evaluation framework can be seen in Figure 2 below. 


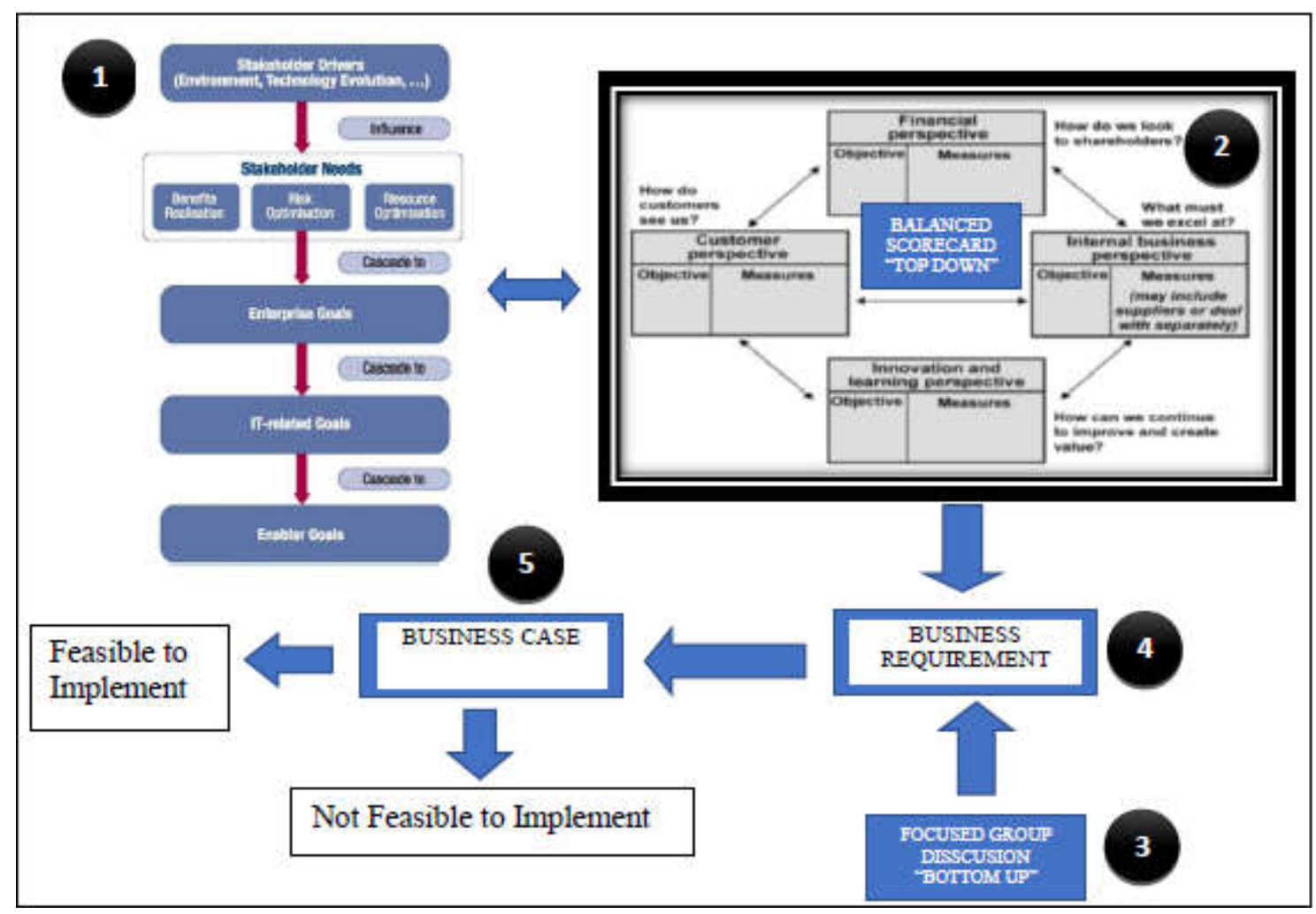

Figure 2. Evaluation Model Framework

As shown in Figure 2, the evaluation procedures consists of the following steps:

1. Step 1: Aligning IT Goals with Enabler Goals

2. Step 2: Access the Balanced Scorecard

3. Step 3: Focused Group Discussion

4. Step 4: Business Requirement

5. Step 5: Business Case Analysis

It can be seen in the IT Alignment Process \& Business Strategy shown in Figure 2 that IT Strategy Plan is a combination of top and down approaches. In order get initiative from business user, IT team together with business unit generates another IT or digital initiative that comes from the bottom through Focused Group Discussion (FGD) mechanism. It is followed by creating a business case, which is a structured document that is presented in the form of argument / verbal / presentation that explains the subject matter and business needs, as an analysis material to determine IT approval. From the results of the analysis of the business requirement and business case that has been tested, it can be concluded whether the project is feasible or not.

Table 1 shows where in the process we use best practices in accordance with COBIT 5.0 recommendations on managed programs and projects (ISACA, 2015). In this process it must be ensured that every project that is run supports the company's business strategy that has been set. The evaluation method refers table 1- table 3 must be represented as follows:

a. The nature and scope of the project are confirmed and developed: Ensuring a general understanding of the scope and objectives of the project among stakeholders has been formalized so that it can become an assessment parameter at the end of the project.

b. The scope of projects is clearly defined and tied to building or enhancing business capability, that each project carried out has a clear scope of work and ensuring that each project implemented has positive implications for the company.

c. Project time, cost, scope is defined, ensure that each project has been defined in terms of time frame, scope, cost. This will be a benchmark in ensuring that the project carried out has been well planned and becomes a parameter of assessment when the project has been completed to find out whether the project is carried out in accordance with the plan. 
d. Prepare and execute a quality management plan, ensure that there is a quality management plan in a project.

Evaluation of alignment QCD criteria \& Project Management refers to table 3 which is represented as follow

a. Time

Project duration are met with time frame: In this case, it will be checked between the actual project completion period and the planned timeframe of the project. If the period of completion is on time with planning, it will be assessed "Yes" in the assessment table, but otherwise if the project exceeds the planning period, there will be a "no" in the assessment table.

b. Cost

Project costs are met with the project budget allocation: In this case, the actual project cost of the project will be checked with the planned cost of the project. If the cost of completion is in accordance with the planning costs, it will be assessed "Yes" in the assessment table, but conversely if the project costs exceed the planning costs, there will be a "no" in the rating table.

b. Quality

Project scope is met with the initial Project Plan: Ensure that the project scope is carried out in accordance with project planning at the beginning. This is also done to ensure that all the main objectives in the project planning have been carried out entirely.

Project quality is met with user requirements alongside UAT Document as evidence. In this case, it will be checked between the functional quality of the actual project results and the user's request. If the functional quality of the work has fulfilled all user requests, it will be assessed "Yes" in the assessment table, but if the functional quality of the work does not meet the user's request, it will be assessed "no" in the rating table.

Each project is monitored after implemented to ensure quality, ensure that projects that have been implemented are monitored and carried out with close supervision to ensure that the implemented projects are properly implemented and can be used properly by the user. Project Management ensure that there is control and monitoring on each project throughout the life of the project. This can be ensured with a periodic progress report as evidence.

For the validation, Expert Judgment method is used. The used parameters in this study are reviewed by experts who are involved in the related use cases. It is hoped that that the method used in this study can raise the level of accuracy of project implementation as a basis for secondary empirical data evaluation.

\section{Results and Discussion}

This analysis data uses $70 \%$ of Empirical Data. This analysis uses using Evaluation method that supports several criteria as explained in the evaluation method. The results obtained are shown in Figure 3 below. 


\begin{tabular}{|c|c|c|c|c|c|c|c|c|c|c|c|c|c|}
\hline \multirow[b]{2}{*}{ No. } & \multirow[b]{2}{*}{ Project Name } & \multirow[b]{2}{*}{$\begin{array}{c}\text { Alignment } \\
\text { of IT project } \\
\text { and business } \\
\text { strategy }\end{array}$} & \multirow[b]{2}{*}{$\begin{array}{c}\text { Alignment of IT } \\
\text { project and IT } \\
\text { Proggrame }\end{array}$} & \multicolumn{4}{|c|}{ Plan } & \multirow[b]{2}{*}{\begin{tabular}{|l}
\multicolumn{1}{c}{ Time } \\
Project \\
duration are \\
met with \\
time frame
\end{tabular}} & \multirow[b]{2}{*}{\begin{tabular}{l}
\multicolumn{1}{c}{ Cost } \\
Project Cost \\
are met with \\
project \\
budget \\
alocation
\end{tabular}} & \multicolumn{3}{|c|}{ Project Quality } & \multirow[b]{2}{*}{\begin{tabular}{l}
\multicolumn{1}{c}{ Project Management } \\
Project are maintened and \\
monitored that supported \\
by project progress report \\
as evidence
\end{tabular}} \\
\hline & & & & $\begin{array}{l}\text { Nature and } \\
\text { scope of the } \\
\text { project are } \\
\text { confirmed and } \\
\text { developed }\end{array}$ & $\begin{array}{l}\text { The scope of } \\
\text { projects are } \\
\text { clearly } \\
\text { defined and } \\
\text { tied to } \\
\text { building or } \\
\text { enhancing } \\
\text { business } \\
\text { capability. }\end{array}$ & $\begin{array}{l}\text { Project time, } \\
\text { cost, scope } \\
\text { are defined }\end{array}$ & $\begin{array}{l}\text { Prepare and } \\
\text { execute a } \\
\text { quality } \\
\text { management } \\
\text { plan }\end{array}$ & & & $\begin{array}{l}\text { Project } \\
\text { scope are } \\
\text { met with } \\
\text { initial } \\
\text { Project Plan }\end{array}$ & $\begin{array}{l}\text { Project } \\
\text { quality are } \\
\text { met with } \\
\text { user } \\
\text { requirement } \\
\text { alongside } \\
\text { UAT } \\
\text { Document as } \\
\text { evidence }\end{array}$ & $\begin{array}{l}\text { Each project } \\
\text { are } \\
\text { monitored or } \\
\text { baby sitted } \\
\text { after } \\
\text { implemented } \\
\text { to ensure } \\
\text { quality }\end{array}$ & \\
\hline 1 & $\begin{array}{l}\text { Automatic } \\
\text { Creating Order }\end{array}$ & Yes & Yes & Yes & Yes & Yes & No & No & No & Yes & Yes & No & No \\
\hline 2 & $\begin{array}{l}\text { Business Contract } \\
\text { Application }\end{array}$ & Yes & Yes & Yes & Yes & Yes & No & Yes & Yes & Yes & Yes & No & Yes \\
\hline 3 & $\begin{array}{l}\text { Project } \\
\text { Management } \\
\text { System }\end{array}$ & Yes & Yes & Yes & Yes & Yes & Yes & Yes & Yes & Yes & Yes & Yes & Yes \\
\hline 4 & $\begin{array}{l}\text { Manpower } \\
\text { Assignment } \\
\text { Tracking } \\
\end{array}$ & Yes & Yes & Yes & Yes & No & Yes & Yes & Yes & Yes & Yes & No & No \\
\hline 5 & MDR Creation & Yes & Yes & Yes & Yes & Yes & Yes & Yes & Yes & Yes & Yes & Yes & Yes \\
\hline 6 & $\begin{array}{l}\text { Automatic } \\
\text { Condemn Tag }\end{array}$ & Yes & Yes & Yes & Yes & Yes & Yes & Yes & Yes & Yes & Yes & Yes & Yes \\
\hline 7 & $\begin{array}{l}\text { Customer } \\
\text { Perspective } \\
\text { Dashboard } \\
\end{array}$ & Yes & Yes & Yes & Yes & Yes & Yes & Yes & Yes & Yes & Yes & Yes & Yes \\
\hline 8 & $\begin{array}{l}\text { Material } \\
\text { Receiving \& } \\
\text { Inspection } \\
\text { System }\end{array}$ & Yes & Yes & Yes & Yes & Yes & Yes & Yes & Yes & Yes & Yes & Yes & Yes \\
\hline 9 & $\begin{array}{l}\text { Performance \& } \\
\text { Goal } \\
\text { Management } \\
\text { Compensasition }\end{array}$ & Yes & Yes & Yes & Yes & Yes & No & Yes & Yes & Yes & Yes & Yes & Yes \\
\hline 10 & $\begin{array}{l}\text { Recruiting \& } \\
\text { Onboard }\end{array}$ & Yes & Yes & Yes & Yes & Yes & No & Yes & Yes & Yes & Yes & Yes & Yes \\
\hline 11 & $\begin{array}{l}\text { IFCS Visitor } \\
\text { Management } \\
\text { System } \\
\end{array}$ & Yes & Yes & Yes & Yes & Yes & Yes & Yes & Yes & Yes & Yes & Yes & Yes \\
\hline 12 & $\begin{array}{l}\text { Covenant } \\
\text { Dashboard }\end{array}$ & Yes & Yes & Yes & Yes & Yes & No & Yes & Yes & Yes & Yes & Yes & Yes \\
\hline 13 & $\begin{array}{l}\text { Content } \\
\text { Management } \\
\text { System - Phase1 }\end{array}$ & Yes & Yes & Yes & Yes & Yes & Yes & Yes & Yes & Yes & Yes & Yes & Yes \\
\hline \multicolumn{2}{|l|}{ Total Yes } & 13 & 13 & 13 & 13 & 12 & 8 & 12 & 12 & 13 & 13 & 10 & 11 \\
\hline \multicolumn{2}{|l|}{ Total No } & 0 & 0 & 0 & 0 & 1 & 5 & 1 & 1 & 0 & 0 & 3 & 2 \\
\hline \multicolumn{2}{|c|}{ Total Done without evidence } & 0 & 0 & 0 & 0 & 0 & 0 & 0 & 0 & 0 & 0 & 0 & 0 \\
\hline \multicolumn{2}{|c|}{ Total } & 13 & 13 & 13 & 13 & 13 & 13 & 13 & 13 & 13 & 13 & 13 & 13 \\
\hline \multicolumn{2}{|c|}{ Yes Percentage } & $100 \%$ & $100 \%$ & $100 \%$ & $100 \%$ & $92 \%$ & $62 \%$ & $92 \%$ & $92 \%$ & $100 \%$ & $100 \%$ & $77 \%$ & $85 \%$ \\
\hline \multicolumn{2}{|c|}{ No Percentage } & $0 \%$ & $0 \%$ & $0 \%$ & $0 \%$ & $8 \%$ & $38 \%$ & $8 \%$ & $8 \%$ & $0 \%$ & $0 \%$ & $23 \%$ & $15 \%$ \\
\hline \multicolumn{2}{|c|}{ Done Without Evidence Percen } & $0 \%$ & $0 \%$ & $0 \%$ & $0 \%$ & $0 \%$ & $0 \%$ & $0 \%$ & $0 \%$ & $0 \%$ & $0 \%$ & $0 \%$ & $0 \%$ \\
\hline
\end{tabular}

Figure 3. Evaluation Model Framework

Based on the results of the Analysis there are several important points which are of concern as follows:

1. Plan, there is 1 project that has not defined Project time, cost, scope project and there are 5 projects that have not defined the Prepare and execute a quality management plan

2. Time, there is 1 project that is not suitable between the project completion time and the planned time frame

3. Cost, there is 1 project that is not suitable between the cost project and the budget allocation that has been provided

4. Project Quality, there are 3 projects that have not been monitored after implementation 
5. Project Quality, there are 2 projects that have not been properly maintained

Based on these results it is known, there are still projects that are not well controlled and monitored, which causes the fulfillment of QCD not to reach $100 \%$.

1. Plan: Prepare and execute a quality management plan (88\%)

2. Time: Project duration are met with time frame (92\%)

3. Project Quality: Each project is not monitored or baby sitted after implemented to ensure quality with result $(92 \%)$

4. Project Management: Project are maintained and monitored that supported by project progress report as evidence $(85 \%)$

\section{Conclusion}

Based on result of the evaluation \& modelling framework in project management that has passed this framework has been proven there are 13 projects can be executed in accordance with stakeholder needs which can provide the accuracy of project quality, time, cost based on COBIT criteria. From research conducted with proven through expert judgment, it is known that the method used in this study can raise the level of accuracy of project implementation.

\section{References}

Hosseinbeig, S., Moghadam, D. K., Vahdat, D., \& Moghadam, R. A. (2011). Combination of IT Strategic Alignment and IT Governance to Evaluate Strategic Alignment Maturity.

Copy, P., \& Indrajit, R. E. (n.d.). Personal Copy of: Prof. Richardus Eko Indrajit.

Kaplan, R. S., \& David, P. (2007). Using the Balanced Scorecard as a Strategic Management System. Harvard Business Review • Managing for the Long Term • July-august 2007.

Of, A. B., \& Practices, C. B. (n.d.). Measures of Project Management Performance and Value.

PMI. (2010). The Value of Project Management. Project Management Institution, 1-6. https://doi.org/10.1002/pmj.20105

Singh, H. (2016). Project Management Analytics: A Data-Driven Approach to Making Rational and Effective Project Decisions.

Rincon, I. (2012). COBIT and project management: how to align your project management practices with the leading IT governance framework. Paper presented at PMI ${ }^{\circledR}$ Global Congress 2012 North America, Vancouver, British Columbia, Canada. Newtown Square, PA: Project Management Institute.

Rooswati, R. (2018). Evaluation Of IT Project Management Governance Using Cobit 5 Framework In Financing Company, (September), 81-85.

ISACA. (2015). COBIT 5 Customized Process Reference Guide. Cobit 5. 